\title{
REVISED Intraocular pressure elevation precedes a phagocytosis decline in a model of pigmentary glaucoma [version 2; peer
}

\section{review: 2 approved]}

\author{
Yalong Dang (D1, Susannah Waxman1, Chao Wang (D1,2, Priyal Shah (D1, \\ Ralitsa T. Loewen'1, Nils A. Loewen (iD) \\ ${ }^{1}$ Department of Ophthalmology, University of Pittsburgh School of Medicine, Pittsburgh, PA, 15213, USA \\ ${ }^{2}$ Department of Ophthalmology, Xiangya Hospital of Central South University, Changsha, Hunan, 410008, China
}

V2 First published: 12 Feb $2018,7: 174$

https://doi.org/10.12688/f1000research.13797.1

Latest published: 09 Apr 2018, 7:174

https://doi.org/10.12688/f1000research.13797.2

\section{Abstract}

Background: Outflow regulation and phagocytosis are key functions of the trabecular meshwork (TM), but it is not clear how the two are related in secondary open angle glaucomas characterized by an increased particle load. We hypothesized that diminished TM phagocytosis is not the primary cause of early ocular hypertension and recreated pigment dispersion in a porcine ex vivo model. Methods: Sixteen porcine anterior chamber cultures received a continuous infusion of pigment granules (Pg), while 16 additional anterior chambers served as controls (C). Pressure transducers recorded the intraocular pressure (IOP). The phagocytic capacity of the trabecular meshwork was determined by fluorescent microspheres.

Results: The baseline IOPs in Pg and $C$ were similar $(P=0.82)$. A significant IOP elevation occurred in $\mathrm{Pg}$ at 48, 120, and 180 hours (all $P$ $<0.01$, compared to baseline). The pigment did not cause a reduction in TM phagocytosis at 48 hours when the earliest IOP elevation occurred, but at 120 hours onward ( $P=0.001$ compared to $C$ ). This reduction did not result in an additional IOP increase at 120 or 180 hours compared to the first IOP elevation at 48 hours $(P>0.05)$. Conclusions: In this porcine model of pigmentary glaucoma, an IOP elevation occurs much earlier than when phagocytosis fails, suggesting that two separate mechanisms might be at work.

\section{Keywords}

Pigment dispersion glaucoma, aqueous outflow, trabecular meshwork, intraocular pressure, phagocytosis

Open Peer Review
Approval Status
version 2
(revision)
09 Apr 2018
12 Feb 2018
1. Sergio C Saccà (iD), RCCS San Martino
University Hospital, Genoa, Italy
2. Don S. Minckler, University of California,
Irvine, USA
Any reports and responses or comments on the
article can be found at the end of the article.




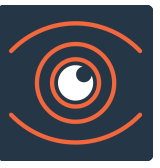

This article is included in the Eye Health

gateway.

Corresponding author: Nils A. Loewen (loewen.nils@gmail.com)

Author roles: Dang Y: Conceptualization, Data Curation, Formal Analysis, Investigation, Methodology, Validation, Visualization, Writing Original Draft Preparation, Writing - Review \& Editing; Waxman S: Data Curation, Investigation, Validation, Writing - Original Draft Preparation; Wang C: Data Curation, Formal Analysis, Investigation, Methodology, Validation; Shah P: Data Curation, Investigation, Methodology, Writing - Review \& Editing; Loewen RT: Formal Analysis, Investigation, Methodology; Loewen NA: Conceptualization, Data Curation, Formal Analysis, Funding Acquisition, Investigation, Methodology, Project Administration, Resources, Supervision, Validation, Writing - Original Draft Preparation, Writing - Review \& Editing

Competing interests: No competing interests were disclosed.

Grant information: NIH CORE Grant P30 EY08098 to the Department of Ophthalmology, from the Eye and Ear Foundation of Pittsburgh, and from an unrestricted grant from Research to Prevent Blindness, New York, NY; National Eye Institute K08EY022737 (NAL); Initiative to Cure Glaucoma of the Eye and Ear Foundation of Pittsburgh (NAL); Research to Prevent Blindness, Departmental Grant (NAL); the Wiegand Fellowship of the Eye and Ear Foundation (YD); an unrestricted grant from the Third Xiangya Hospital of Central South University for studying at the University of Pittsburgh (CW).

The funders had no role in study design, data collection and analysis, decision to publish, or preparation of the manuscript.

Copyright: ( 2018 Dang Y et al. This is an open access article distributed under the terms of the Creative Commons Attribution License, which permits unrestricted use, distribution, and reproduction in any medium, provided the original work is properly cited. Data associated with the article are available under the terms of the Creative Commons Zero "No rights reserved" data waiver (CC0 1.0 Public domain dedication).

How to cite this article: Dang Y, Waxman S, Wang $C$ et al. Intraocular pressure elevation precedes a phagocytosis decline in a model of pigmentary glaucoma [version 2; peer review: 2 approved] F1000Research 2018, 7:174

https://doi.org/10.12688/f1000research.13797.2

First published: 12 Feb 2018, 7:174 https://doi.org/10.12688/f1000research.13797.1 


\section{REVISED Amendments from Version 1}

We have modified the Introduction to include more details about conventional outflow mechanisms. We emphasize more clearly in the Introduction and Discussion that we do not think that pigmentary debris causes a physical outflow obstruction.

See referee reports

\section{Introduction}

The conventional outflow is guarded by the trabecular meshwork (TM), a complex three dimensional, layered tissue that contains variable amounts of extracellular matrix $(\mathrm{ECM})^{1}$. The aqueous passes from the anterior chamber into Schlemm's canal (SC) by entering first the uveal TM (UTM), the corneoscleral TM (CTM) and finally the juxtacanalicular TM (JCT) ${ }^{2}$. The JCT contains proteoglycans and hyaluronans and presents the aqueous humor with an increasingly tighter fluid passageway towards the $\mathrm{SC}$ in a process referred to as funneling ${ }^{3}$. The aqueous eventually passes the inner wall of SC endothelium mainly by two different mechanisms, a paracellular route in between endothelial cells and a transcellular route ${ }^{4}$ consisting of intracellular pores and giant vacuoles that are time and pressure dependent ${ }^{1,5,6}$. Failure of the TM and the inner wall of SC endothelial cells to maintain homeostasis and a normal cytoskeleton and can cause ocular hypertension ${ }^{7}$. For instance, pigment dispersion $^{8}$ and corticosteroids can increase and contract actin stress fibers and result in an elevation of the intraocular pressure (IOP) $)^{8,9}$. Conversely, relaxing the cytoskeleton with Rho kinase inhibitors can reverse these effects ${ }^{10,11}$. Phagocytosis of debris is another function of TM cells ${ }^{1}$. A chronic phagocytosis demand in the form of pigment ${ }^{12}$, erythrocyte-derived ghost cells $^{13}$, inflammatory cells ${ }^{14}$, photoreceptor outer segments ${ }^{15}$, lens and pseudoexfoliation material ${ }^{16,17}$ can all lead to secondary glaucomas even though the amount of material itself is unlikely to cause a physical outflow obstruction. Although these glaucomas make for a sizable fraction of open angle glaucomas, it was difficult to study the cellular mechanism that leads to an IOP elevation.

We recently developed a porcine ex vivo pigmentary glaucoma (PG) model that recreates the IOP elevation, stress fiber formation, and phagocytosis reduction that are characteristic of human $\mathrm{PG}^{8}$. A gene expression analysis indicated an activation of the RhoA signaling pathway and a downstream effect of tight junction formation negatively regulated by RhoA-mediated actin cytoskeletal reorganization ${ }^{8}$. In the current study, we hypothesized that early ocular hypertension from pigment dispersion is the result of actin cytoskeletal changes and occurs before phagocytosis declines.

\section{Methods}

Pig eye perfusion culture and pigmentary glaucoma model This study was conducted in accordance with the Association for Research in Vision and Ophthalmology Statement for the Use of Animals in Ophthalmic and Vision Research. Because no live vertebrate animals were used and pig eyes were acquired from a local abattoir (Thoma Meat Market, Saxonburg, PA), no Institutional Animal Care and Use approval was required.

Thirty-two porcine eyes were cultured within 2 hours of enucleation. Extraocular tissues were removed, and the eyes were decontaminated with $5 \%$ povidone-iodine solution (CAT\# 3955-16, United States Pharmacopeia, Rockville, MD) for two minutes and washed three times in phosphate buffered saline (PBS). Posterior segments, lenses, and irises were removed and the anterior segments with intact TM mounted in the perfusion system as previously described ${ }^{8,18,19}$. We used the same method to generate pigment granules as recently described in a model of pigmentary glaucoma $(\mathrm{PG})^{8}$. Briefly, pigment granules were produced by subjecting the iris to freezethaw and resuspension washing before dilution of the stock to a final concentration of $1.67 \times 10^{7}$ particles $/ \mathrm{ml}$. Eyes in the pigment dispersion group were continuously perfused with pigment added to the culture medium for up to 180 hours (Pg) and compared to controls (C). The perfusate consisted of Dulbecco's modified Eagle media (DMEM, SH30284, HyClone, GE Healthcare, UK) supplemented with $1 \%$ FBS and $1 \%$ antibiotics (15240062, Thermo Fisher Scientific, Waltham, MA) at a constant rate of $3 \mu \mathrm{l} / \mathrm{min}$ using a microinfusion pump (PHD 22/2000; Harvard Apparatus, Holliston, MA). IOP was measured intracamerally by a pressure transducer (SP844; MEMSCAP, Skoppum, Norway) and recorded at two-minute intervals (LabChart, ADInstruments, Colorado Springs, CO). Baseline IOPs were obtained after IOP stabilization for 48 hours.

\section{TM phagocytosis}

The in situ TM phagocytosis was measured using an epifluorescence microscope after microsphere perfusion. In brief, a suspension of $0.5 \mu \mathrm{m}$ carboxylate-modified yellow-green fluorescent microspheres ${ }^{20}$ (CAT\# F8813, Thermo Fisher, Waltham, MA) at $5 \times 10^{8}$ particles $/ \mathrm{ml}$ was added to the perfusate at 48,120 , and 180 hours and perfused for 24 hours. The eyes were removed from their perfusion dishes, washed three times with prewarmed PBS, secured again in the perfusion dishes, and placed upside down for imaging. The TM, visualized from the underside of the transparent perfusion dish, was photographed and measured by acquiring the images with a camera and epifluorescence equipped dissecting fluorescence microscope (SZX16, Olympus, Tokyo, Japan) at a $680 \times 510$ pixel resolution and a $200 \mathrm{~ms}$ exposure. The mean fluorescence intensity was quantified by ImageJ (Version $1.50 \mathrm{i}, \mathrm{NIH}$ ) as previously described ${ }^{21}$ at 48,120 , and 180 hours by measuring the fluorescence intensity in the TM.

To validate that the microspheres were phagocytosed by TM cells, the TM was dissected and digested with collagenase type IA (C9891, Sigma Aldrich, St. Louis, MO) at $2 \mathrm{mg} / \mathrm{ml}$ and $1 \%$ FBS for $30 \mathrm{~min}$ at room temperature. The cells were filtered with a 70-micron cell strainer and resuspended in $0.5 \mathrm{ml}$ of PBS. The percentage of TM cells that had ingested fluorescent microspheres was determined using flow cytometry. 
To get a more accurate visualization of the phagocytosed microbeads, we used confocal microscopy. TM cells were seeded into the wells of a six-well plate and fixed with $4 \%$ PFA. The cell membranes were labeled with Lycopersicon esculentum agglutinin (TL; Texas red-conjugated; \#TL-1176, Vector Laboratories, Inc., Burlingame, CA) at room temperature for 1 hour. The cell nuclei were counterstained with DAPI (D1306, Thermo Fisher Scientific, Waltham, MA). Photos and 3D videos were taken using an upright laser scanning confocal at 400x magnification (BX61, Olympus, Tokyo, Japan).

\section{Histology}

After the TM phagocytosis assay, the anterior segments were fixed with 4\% PFA for 24 hours, washed three times with PBS, dehydrated in $70 \%$ ethanol, and embedded in paraffin. Sections were cut to a thickness of $5 \mu \mathrm{m}$ and stained with hematoxylin and eosin $(\mathrm{H} \& \mathrm{E})$.

\section{Statistics}

Data were presented as the mean \pm standard error and analyzed by PASW Statistics 18 (SPSS Inc., Chicago, IL). The baseline IOP was compared to the other time points of the same eye using a paired $t$-test. Other quantitative data were analyzed by one-way ANOVA. A $p$ value $\leq 0.05$ was considered statistically significant.

\section{Results}

In H\&E stained tissue sections, normal TM (Figure 1A) presented as a sparsely pigmented (red arrowheads), multilayered, porous tissue with Schlemm's canal-like segments within the aqueous plexus at the outer layer (black arrows). Pigment granules were seen phagocytosed by trabecular meshwork cells, particularly in the uveal TM, at 48, 120, and 180 hours (Figure 1B, C and D) but were not dense enough to physically obstruct any part of the conventional outflow system.
Baseline IOP in Pg was comparable to C $(12.2 \pm 0.9 \mathrm{mmHg}$ vs. $11.9 \pm 0.9 \mathrm{mmHg}, P=0.82)$. Pigment dispersion caused a significant IOP elevation at 48,120 , and 180 hours $(19.5 \pm 1.4 \mathrm{mmHg}$, $20.2 \pm 1.4 \mathrm{mmHg}$ and $22.8 \pm 0.8 \mathrm{mmHg}, P=0.001, P<0.001$ and $P=0.002$, compared to baseline) while IOPs in $\mathrm{C}$ remained steady $(13.1 \pm 1.1 \mathrm{mmHg}, 12.0 \pm 0.9 \mathrm{mmHg}$ and $14.0 \pm 1.5 \mathrm{mmHg}$, all $p$ values $>0.05$, compared to baseline) (Figure $2 \mathrm{~A}$ ).

By inverting the perfusion dishes and washing away the microspheres in the intertrabecular spaces, the TM phagocytosis was visualized and quantified under an upright dissecting fluorescence microscope. Pigment did not cause any change of phagocytosis during early ocular hypertension at 48 hours (Figure 2Bi-ii, 96.3 $\pm 5.0 \%$ compared to the control, $P=0.723$ ), but did cause a reduction at the later phases of 120 hours (Figure 2Biii-iv, $58.3 \pm 2.3 \%, \quad P=0.001$ ) and 180 hours (Figure2Bv-vi, $62.5 \pm 5.1 \%, \quad P=0.026$ ). However, the declining phagocytosis did not result in further elevation of IOP at 120 and 180 hours compared to the initial IOP elevation at 48 hours $(20.2 \pm 1.4 \mathrm{mmHg}$ and $22.8 \pm 0.8 \mathrm{mmHg}$ versus $19.5 \pm 1.4$ $\mathrm{mmHg}$, both $P>0.05)$.

The microsphere ingestion by TM cells was further assessed by flow cytometry and confocal microscopy. $28.1 \%$ of TM cells had phagocytosed microbeads in a normal perfusion eye (Figure 3A) and the confocal microscopy confirmed them as being located within the cells (Figure 3B) aided by tomato lectin-stained cell membranes and DAPI-stained nuclei. Confocal imaging showed clusters of green fluorescent microspheres within the intracellular space with no microspheres in the intercellular space. The 3D video also suggested the microspheres were in fact phagocytized and not merely on top of or below them since the microbeads were in the same $\mathrm{z}$ plane as the cells (Supplementary Video 1).
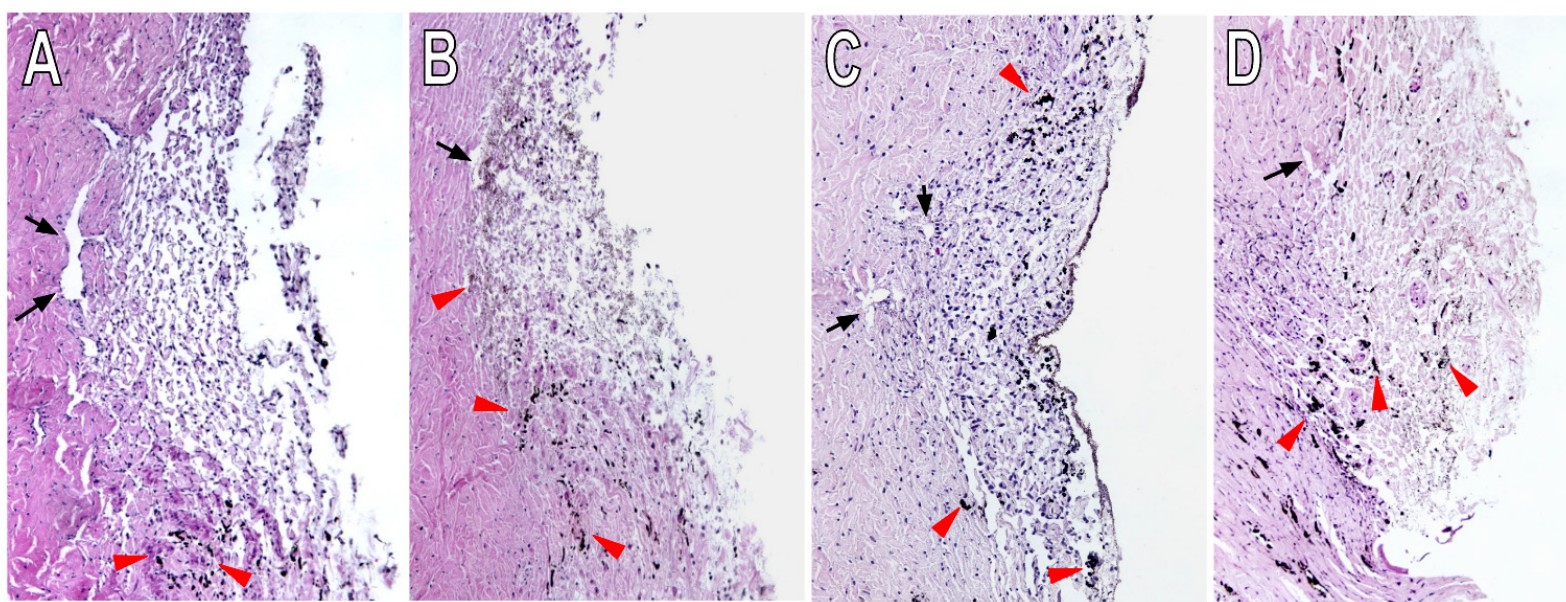

Figure 1. Histology. Normal trabecular meshwork (TM) (A) was a multilayer, strainer-like structure with few pigment deposits (red arrowheads). Ex vivo perfusion with pigment granules at $1.67 \times 10^{7} / \mathrm{ml}$ caused significant TM pigmentation at 48 hours (B), 120 hours (C) and 180 hours (D). No apparent occlusion of the outflow tract was found. 


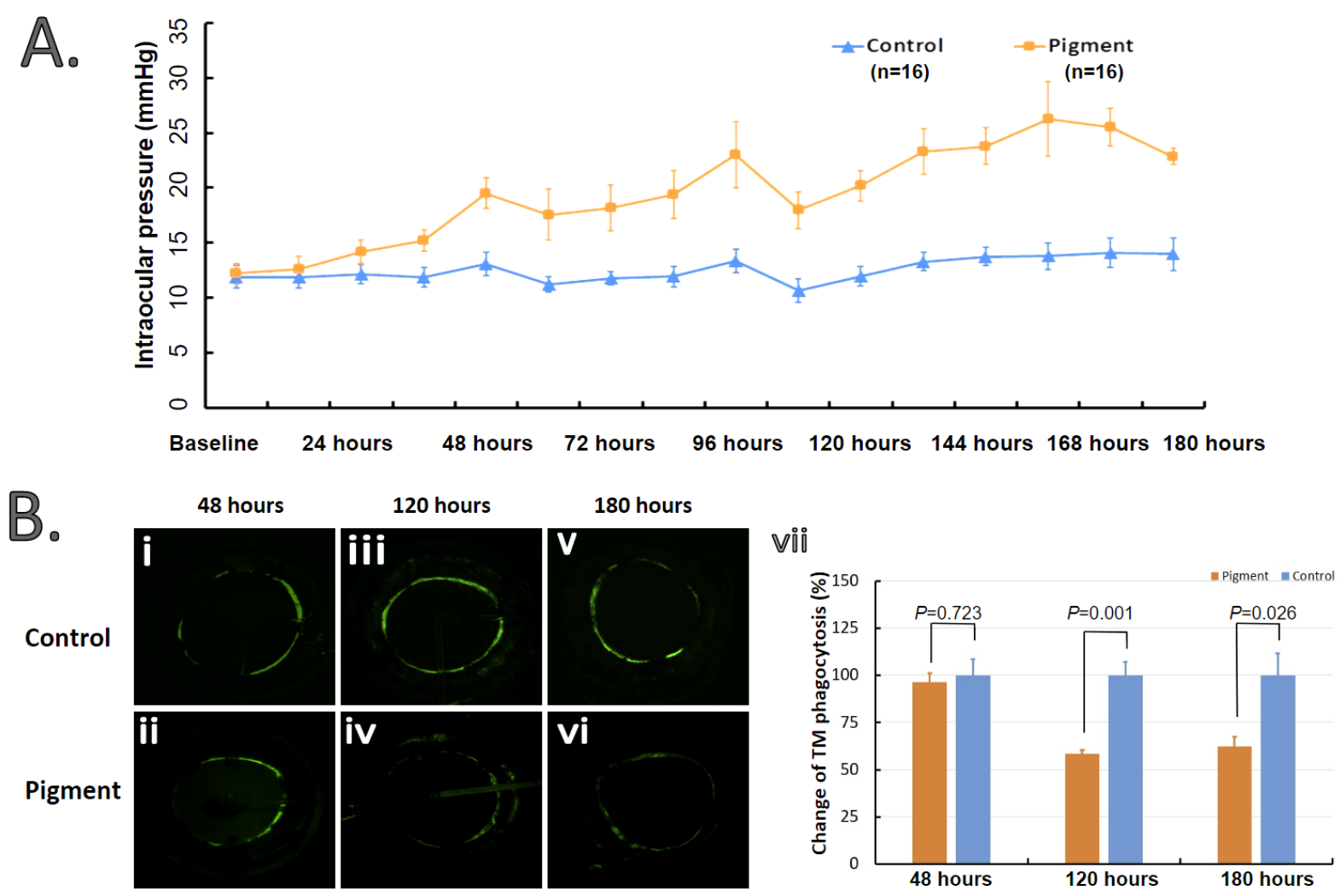

Figure 2. Reduction of intraocular pressure and TM phagocytic activity by pigment dispersion. Baseline IOPs in the pigment group $(n=16)$ and the control $(n=16)$ are comparable $(12.2 \pm 0.9 \mathrm{mmHg}$ vs. $11.9 \pm 0.9 \mathrm{mmHg}, P=0.82)$. Pigment caused a significant IOP elevation at 48 hours and onward (all $P<0.05$ ) while the IOP in the control group showed no significant difference to baseline at any time point (all $P>0.05)$ when compared to the baseline (A). TM phagocytosis was visualized in situ. The mean fluorescence intensity in the TM region was quantified by NIH ImageJ. TM phagocytosis in the pigment group was comparable to the control at 48 hours $(P=0.723)$, (Bi-ii) but showed sharp decreases at 120 hours (Biii-iv) and 180 hours ( $P=0.001$ and $P=0.026$, respectively) (Bv-vi).

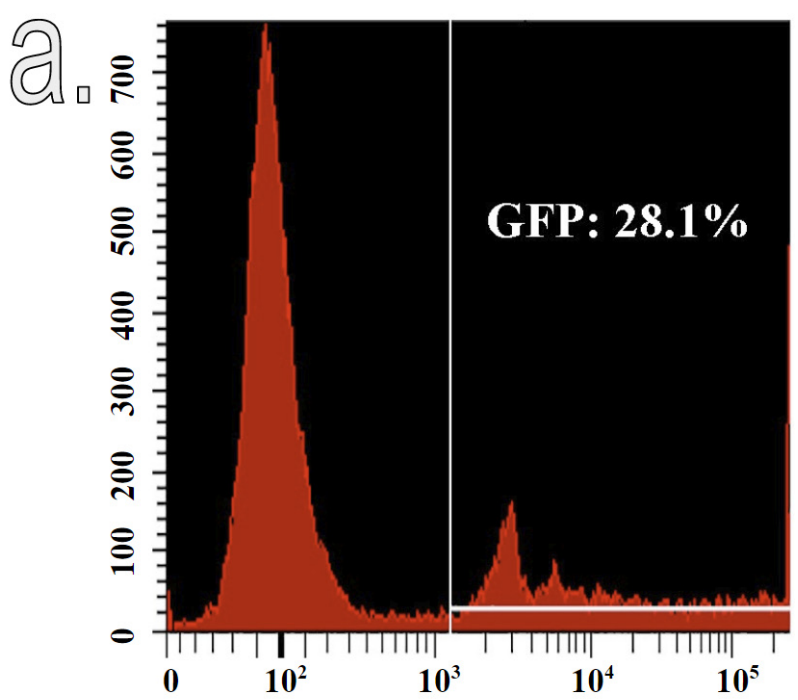

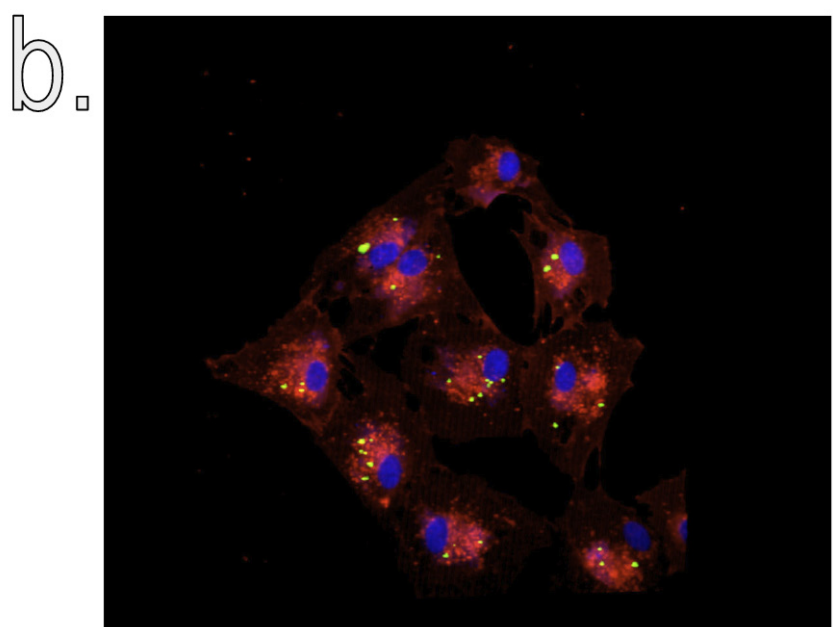

Tomato Lectin $647 \mathrm{~nm} / \mathrm{GFP}$

Figure 3. Validation of TM phagocytosis by flow cytometry and confocal microscopy. To further confirm that microspheres were phagocytosed, we digested a normal sample TM tissue into single cell suspension and sent for flow cytometry. The results suggested that $28.1 \%$ of the TM cells were actively phagocytic $(\mathbf{A})$. We then seeded these cells into a six well plate to form monolayer. After labeling them with tomato lectin, the confocal imaging showed that clusters of green fluorescent microspheres were located in the intracellular but not in the intercellular space (B). 
Dataset 1. Raw unedited images of Figure 1

http://dx.doi.org/10.5256/f1000research.13797.d192088

They are representative of 17 slides for histology.

Dataset 2. Raw unedited images of Figure 2B

http://dx.doi.org/10.5256/f1000research.13797.d192089

They are representative of 31 pictures for phagocytosis measurement.

Dataset 3. Raw unedited images of Figure 3B

http://dx.doi.org/10.5256/f1000research.13797.d192090

Dataset 4. The FACS output file for Figure 3A

http://dx.doi.org/10.5256/f1000research.13797.d192091

Dataset 5. The raw IOP and phagocytosis measurements at all time points

http://dx.doi.org/10.5256/f1000research.13797.d192092

\section{Discussion}

Phagocytosis is a defining feature of $\mathrm{TM}$ cells ${ }^{22}$ and plays a central but poorly understood role in the pathogenesis of secondary glaucomas caused by particulate matter such as erythrocytes and ghost cells, inflammatory cells, outer photoreceptor segments, lens and pseudoexfoliation material and pigmentary debris ${ }^{8,23-25}$. These may interfere with various intracellular processes resulting in a gradual deterioration of outflow $^{23,26}$. Although TM phagocytosis can remove particles from the aqueous humor ${ }^{27}$, the direct, short-term effects on outflow regulation remain insufficiently explained ${ }^{7}$. In this study, we measured IOP and TM phagocytic activity in the presence of pigment granules at different time points and found IOP was significantly elevated as early as 48 hours after exposure to pigment granules. This was contrasted with a phagocytic activity in $\mathrm{Pg}$ not different from $\mathrm{C}$ before the decrease at 120 and 180 hours. A worsening decline of TM phagocytosis at 120 and 180 hours did not result in a further increase of IOP. This suggests that reduction in phagocytosis is a downstream and secondary effect of actin cytoskeletal reorganization.

Past investigations suggested that the outflow obstruction was, in fact, physical ${ }^{12,28}$ but newer studies indicated that ocular hypertension is in part caused indirectly by reorganization of the TM actin cytoskeleton ${ }^{29}$. This occurs at a concentration far lower $(10,000 \text {-fold })^{8}$ than that used in previous bolus experiments $^{12}$. Consistent with Zhou et al..$^{29}$, we recently reported that long, thick, and continuous TM actin bundles emerge as early as 24 hours after pigment exposure ${ }^{8}$ and replicate this observation in the present study. Histological characteristics of pigment dispersion in porcine eyes matched those seen in samples from pigmentary glaucoma patients $\mathrm{s}^{28,30,31}$ showing that pigment particles were taken up by TM cells.

In summary, the results confirm that the IOP elevation caused by pigment dispersion is not the direct result of physical obstruction of outflow or a chronically overwhelmed phagocytosis. The reduction in phagocytosis considerably lags the evolving hypertension supporting the notion that these cytoskeletal changes occur early on and are separate from the impact of pigment on canonical phagocytosis pathways ${ }^{8}$.

\section{Data availability}

All the raw data generated or analyzed in this study are included in following datasets.

Dataset 1. Raw unedited images of Figure 1. They are representative of 17 slides for histology. 10.5256/f1000research.13797.d192088 24

Dataset 2. Raw unedited images of Figure 2B. They are representative of 31 pictures for phagocytosis measurement. 10.5256/ f1000research.13797.d192089 25

Dataset 3. Raw unedited images of Figure 3B. 10.5256/ f1000research.13797.d19209026

Dataset 4. The FACS output file for Figure 3A. 10.5256/ f1000research.13797.d19209127

Dataset 5. The raw IOP and phagocytosis measurements at all time points. 10.5256/f1000research.13797.d192092 ${ }^{28}$

\section{Competing interests}

No competing interests were disclosed.

\section{Grant information}

NIH CORE Grant P30 EY08098 to the Department of Ophthalmology, from the Eye and Ear Foundation of Pittsburgh, and from an unrestricted grant from Research to Prevent Blindness, New York, NY; National Eye Institute K08EY022737 (NAL); Initiative to Cure Glaucoma of the Eye and Ear Foundation of Pittsburgh (NAL); Research to Prevent Blindness, Departmental Grant (NAL); the Wiegand Fellowship of the Eye and Ear Foundation (YD); an unrestricted grant from the Third Xiangya Hospital of Central South University for studying at the University of Pittsburgh (CW).

The funders had no role in study design, data collection and analysis, decision to publish, or preparation of the manuscript. 


\section{Supplementary material}

Supplementary Video 1. Visualization of microsphere ingestion by a 3D reconstruction with confocal microscopy. We took a series of $\mathrm{z}$-stack confocal microscopy images to reconstruct a 3D video, showing that the fluorescent microspheres were neither on the top nor below, but phagocytized by the TM cells.

Click here to access the data.

1. Tamm ER: The trabecular meshwork outflow pathways: structural and functional aspects. Exp Eye Res. 2009; 88(4): 648-55. PubMed Abstract | Publisher Full Text

2. Saccà SC, Gandolfi S, Bagnis A, et al.: The Outflow Pathway: A Tissue With Morphological and Functional Unity. J Cell Physiol. 2016; 231(9): 1876-1893. PubMed Abstract | Publisher Full Text

3. Ethier CR, Coloma FM, Sit AJ, et al:: Two pore types in the inner-wall endothelium of Schlemm's canal. Invest Ophthalmol Vis Sci. 1998; 39(11): 2041-2048. PubMed Abstract

4. Alvarado JA, Betanzos A, Franse-Carman L, et al.: Endothelia of Schlemm's canal and trabecular meshwork: distinct molecular, functional, and anatomic features. Am J Physiol Cell Physiol. 2004; 286(3): C621-C634. PubMed Abstract | Publisher Full Text

5. Johnstone MA, Grant WG: Pressure-dependent changes in structures of the aqueous outflow system of human and monkey eyes. Am J Ophthalmol. 1973; 75(3): 365-383.

PubMed Abstract | Publisher Full Text

6. Braakman ST, Daniel Stamer W, Overby DR: A fluorescent permeability assay for Schlemm's canal endothelial cells in response to stretch. Invest Ophthalmol Vis Sci. 2014; 55(13): 5983.

Reference Source

7. Llobet A, Gasull X, Gual A: Understanding trabecular meshwork physiology: a key to the control of intraocular pressure? News Physiol Sci. 2003; 18(5): 205-9.

PubMed Abstract | Publisher Full Text

8. Dang $\mathrm{Y}$, Waxman $\mathrm{S}$, Wang $\mathrm{C}$, et al:: A porcine ex vivo model of pigmentary glaucoma. Sci Rep. 2018; 8(1): 5468.

PubMed Abstract | Publisher Full Text

9. Pattabiraman PP, Rao PV: Mechanistic basis of Rho GTPase-induced extracellular matrix synthesis in trabecular meshwork cells. Am J Physiol Cell Physiol. 2010; 298(3): C749-63.

PubMed Abstract | Publisher Full Text | Free Full Text

10. Tanihara $\mathrm{H}$, Inoue $\mathrm{T}$, Yamamoto $\mathrm{T}$, et al.: Intra-ocular pressure-lowering effects of a Rho kinase inhibitor, ripasudil (K-115), over 24 hours in primary openangle glaucoma and ocular hypertension: a randomized, open-label, crossover study. Acta Ophthalmol. 2015; 93(4): e254-60. PubMed Abstract | Publisher Full Text

11. Tanihara $\mathrm{H}$, Inoue $\mathrm{T}$, Yamamoto $\mathrm{T}$, et al.: Phase 1 clinical trials of a selective Rho kinase inhibitor, K-115. JAMA Ophthalmol. 2013; 131(10): 1288-95. PubMed Abstract | Publisher Full Text

12. Epstein DL, Freddo TF, Anderson PJ, et al:: Experimental obstruction to aqueous outflow by pigment particles in living monkeys. Invest Ophthalmol Vis Sci. 1986; 27(3): 387-95.

PubMed Abstract

13. Campbell DG, Simmons RJ, Grant WM: Ghost cells as a cause of glaucoma. $A m$ J Ophthalmol. 1976; 81(4): 441-50. PubMed Abstract | Publisher Full Tex

14. Moorthy RS, Mermoud A, Baerveldt G, et al.: Glaucoma associated with uveitis Surv Ophthalmol. 1997; 41(5): 361-94. PubMed Abstract | Publisher Full Text

15. Callender D, Jay JL, Barrie T: Schwartz-Matsuo syndrome: atypical presentation as acute open angle glaucoma. Br J Ophthalmol. 1997; 81(7): 609-10. PubMed Abstract | Publisher Full Text | Free Full Text

16. Lee RK: The molecular pathophysiology of pseudoexfoliation glaucoma. Curr
Opin Ophthalmol. 2008; 19(2): 95-101. PubMed Abstract | Publisher Full Text

17. Ritch $R$, Schlötzer-Schrehardt $U$, Konstas AG: Why is glaucoma associated with exfoliation syndrome? Prog Retin Eye Res. 2003; 22(3): 253-75. PubMed Abstract | Publisher Full Text

18. Loewen RT, Roy P, Park DB, et al.: A Porcine Anterior Segment Perfusion and Transduction Model With Direct Visualization of the Trabecular Meshwork. Invest Ophthalmol Vis Sci. 2016; 57(3): 1338-44. PubMed Abstract | Publisher Full Text | Free Full Text

19. Dang $Y$, Waxman S, Wang C, et al:: Freeze-thaw decellularization of the trabecular meshwork in an ex vivo eye perfusion model. Peer J Preprints. 2017; 5: e2736v1. Publisher Full Text

20. Loewen RT, Brown EN, Scott G, et al:: Quantification of Focal Outflow Enhancement Using Differential Canalograms. Invest Ophthalmol Vis Sci. 2016; 57(6): 2831-8.

PubMed Abstract | Publisher Full Text | Free Full Text

21. Dang $Y$, Waxman $S$, Wang $C$, et al:: Rapid learning curve assessment in an ex vivo training system for microincisional glaucoma surgery. PeerJ Preprints. 2017; 5: e2745v1.

Publisher Full Text

22. Buller C, Johnson DH, Tschumper RC: Human trabecular meshwork phagocytosis. Observations in an organ culture system. Invest Ophthalmol Vis Sci. 1990; 31(10): 2156-63. PubMed Abstract

23. Liton PB, Lin Y, Gonzalez P, et al:: Potential role of lysosomal dysfunction in the pathogenesis of primary open angle glaucoma. Autophagy. 2009; 5(1): 122-4. PubMed Abstract | Publisher Full Text | Free Full Text

24. Zhang $\mathrm{X}$, Ognibene $\mathrm{CM}$, Clark $\mathrm{AF}$, et al:: Dexamethasone inhibition of trabecular meshwork cell phagocytosis and its modulation by glucocorticoid receptor beta. Exp Eye Res. 2007; 84(2): 275-84. PubMed Abstract | Publisher Full Text | Free Full Text

25. Sivaraman KR, Patel CG, Vajaranant TS, et al:: Secondary pigmentary glaucoma in patients with underlying primary pigment dispersion syndrome. Clin Ophthalmol. 2013; 7: 561-566.

PubMed Abstract | Publisher Full Text | Free Full Text

26. Saccà SC, Gandolfi S, Bagnis A, et al:: From DNA damage to functional changes of the trabecular meshwork in aging and glaucoma. Ageing Res Rev. 2016; 29: 26-41. PubMed Abstract | Publisher Full Text

27. Abu-Hassan DW, Acott TS, Kelley MJ: The Trabecular Meshwork: A Basic Review of Form and Function. J Ocul Biol. 2014; 2(1): pii: http://fulltextarticles.avensonline. org/JOCB-2334-2838-02-0017.html.

PubMed Abstract | Publisher Full Text | Free Full Text

28. Alvarado JA, Murphy CG: Outflow obstruction in pigmentary and primary open angle glaucoma. Arch Ophthalmol. 1992; 110(12): 1769-78. PubMed Abstract | Publisher Full Text

29. Zhou L, LiY, Yue BY: Alteration of cytoskeletal structure, integrin distribution, and migratory activity by phagocytic challenge in cells from an ocular tissue-The trabecular meshwork. In Vitro Cell Dev Biol Anim. 1999; 35(3): 144-149. PubMed Abstract | Publisher Full Text

30. Gottanka J, Johnson DH, Grehn F, et al:: Histologic findings in pigment dispersion syndrome and pigmentary glaucoma. J Glaucoma. 2006; 15(2): 142-51. PubMed Abstract | Publisher Full Text

31. Kupfer $\mathrm{C}$, Kuwabara T, Kaiser-Kupfer M: The histopathology of pigmentary dispersion syndrome with glaucoma. Am J Ophthalmol. 1975; 80(5): 857-62. PubMed Abstract | Publisher Full Text 


\section{Open Peer Review}

\section{Current Peer Review Status:}

\section{Version 2}

Reviewer Report 23 April 2018

https://doi.org/10.5256/f1000research.15759.r33294

(C) 2018 Minckler D. This is an open access peer review report distributed under the terms of the Creative Commons Attribution License, which permits unrestricted use, distribution, and reproduction in any medium, provided the original work is properly cited.

\section{Don S. Minckler}

Gavin Herbert Eye Institute, University of California, Irvine, CA, USA

In my view, this well written report adds clarification to an old problem of explaining the pathogenesis of glaucoma secondary to particulate material in the aqueous. The authors' conclusions should direct additional attention to studying the biomechanics of meshwork functioning especially phagocytosis by the lining endothelial cells. The experimental methods are complex but make sense considering the challenges of the physiology being investigated.

I have no major criticisms and suggest the paper be indexed as is.

Is the work clearly and accurately presented and does it cite the current literature? Yes

Is the study design appropriate and is the work technically sound? Yes

Are sufficient details of methods and analysis provided to allow replication by others? Yes

If applicable, is the statistical analysis and its interpretation appropriate? Yes

Are all the source data underlying the results available to ensure full reproducibility? Yes

Are the conclusions drawn adequately supported by the results? Yes

Competing Interests: No competing interests were disclosed. 
Reviewer Expertise: Management of complex glaucoma, optic nerve injury in glaucoma

I confirm that I have read this submission and believe that I have an appropriate level of expertise to confirm that it is of an acceptable scientific standard.

Reviewer Report 12 April 2018

https://doi.org/10.5256/f1000research.15759.r32895

(C) 2018 Saccà S. This is an open access peer review report distributed under the terms of the Creative Commons Attribution License, which permits unrestricted use, distribution, and reproduction in any medium, provided the original work is properly cited.

\section{Sergio C Saccà}

Department of Neuroscience and Sense Organs, RCCS San Martino University Hospital, Genoa, Italy

I read with interest the new version of the article by Yalong Dang et al. And I'm glad to find out that the authors' ideas match up with mine. I believe that in pigmentary glaucoma there is a defect in the autophagy of the cells of Trabecolato and therefore this version is more in keeping with modern biology. I believe it can now be published.

Is the work clearly and accurately presented and does it cite the current literature? Yes

Is the study design appropriate and is the work technically sound?

Yes

Are sufficient details of methods and analysis provided to allow replication by others? Yes

If applicable, is the statistical analysis and its interpretation appropriate? Yes

Are all the source data underlying the results available to ensure full reproducibility? Yes

Are the conclusions drawn adequately supported by the results? Yes

Competing Interests: No competing interests were disclosed.

Reviewer Expertise: Glaucoma pathogenesis and Molecular biology

I confirm that I have read this submission and believe that I have an appropriate level of expertise to confirm that it is of an acceptable scientific standard. 


\section{Version 1}

Reviewer Report 26 March 2018

https://doi.org/10.5256/f1000research.14999.r32109

(C) 2018 Saccà S. This is an open access peer review report distributed under the terms of the Creative Commons Attribution License, which permits unrestricted use, distribution, and reproduction in any medium, provided the original work is properly cited.

\section{Sergio C Saccà}

Department of Neuroscience and Sense Organs, RCCS San Martino University Hospital, Genoa, Italy

I read the article titled: Intraocular pressure elevation precedes a phagocytosis decline in a model of pigmentary glaucoma by Dang et al. The title of the article is very stimulating but the content has several things that should be corrected. The authors state that in the conventional way of outflow the aqueous passes into Schlemm's canal by paracytosis or giant vacuoles. This is a partial view that does not correspond to the truth. I invite the authors to read Saccà et al. The Outflow Pathway: A Tissue With Morphological and Functional Unity ${ }^{1}$. Then the effects of the inhibitors of the Rho kinase inhibitor may have the ability to modify the metabolism of endothelial cells in the node in which the authors think it is open to question. These drugs have the ability to block TM motility by exposing more cells to aqueous humor. This is the reason why we initially witness a decline in IOP then this worsens because the exposed cells are blocked and are more exposed to apoptosis (to read Saccà et al. from DNA damage to functional changes of the trabecular meshwork in aging and glaucoma ${ }^{2}$ ). Also the hypothesis formulated by the authors to explain the pigmentary glaucoma is partial in the Trabecolato the so-called pores have a very low meaning and above all the pigment does not obstruct anything. We do not work like sinks - I am amazed that today we can still believe that TM is a porous tissue, and above all, how it is possible to think that outflow is a passive phenomenon. In pigmentary glaucoma there are 2 fundamental pathogenic moments. The first concerns the back sheet of the iris, where the pigment comes from (a defect that involves the loss of the pigment itself) the second point concerns autophagy which is not able to ensure adequate cell homeostasis. So these cells first enter suffering and then die and hence glaucoma is why the cells do not work, not because it obstructs something. There are cells, not tubes. The cytoskeleton in all this has little to do with it: pigment granules are only a metabolic burden that in the case of pigment dispersal syndrome is absorbed by a functioning autophagy, while in pigment glaucoma, autophagy does not work. Finally, I remember that the changes in the cytoskeleton occur in all types of glaucoma. I do not believe that this article can be indexed in this form and needs a remake of both the introduction and the discussion and the results should be reviewed in the light of a more modern interpretation of the physio-pathogenical events.

\section{References}

1. Saccà SC, Gandolfi S, Bagnis A, Manni G, et al.: The Outflow Pathway: A Tissue With Morphological and Functional Unity.J Cell Physiol. 2016; 231 (9): 1876-93 PubMed Abstract | Publisher Full Text

2. Saccà SC, Gandolfi S, Bagnis A, Manni G, et al.: From DNA damage to functional changes of the trabecular meshwork in aging and glaucoma.Ageing Res Rev. 2016; 29: 26-41 PubMed Abstract | 


\section{Publisher Full Text}

Is the work clearly and accurately presented and does it cite the current literature? No

Is the study design appropriate and is the work technically sound?

Yes

Are sufficient details of methods and analysis provided to allow replication by others? Yes

If applicable, is the statistical analysis and its interpretation appropriate? Yes

Are all the source data underlying the results available to ensure full reproducibility? Yes

Are the conclusions drawn adequately supported by the results? No

Competing Interests: No competing interests were disclosed.

Reviewer Expertise: Glaucoma pathogenesis and Molecular biology

I confirm that I have read this submission and believe that I have an appropriate level of expertise to state that I do not consider it to be of an acceptable scientific standard, for reasons outlined above.

Author Response 31 Mar 2018

Nils Loewen, University of Pittsburgh School of Medicine, Pittsburgh, USA

Reviewer 1:

I read the article titled: Intraocular pressure elevation precedes a phagocytosis decline in a model of pigmentary glaucoma by Dang et al. The title of the article is very stimulating but the content has several things that should be corrected.

Authors: We thank the reviewer, Professor Saccà, for having taken the time to carefully review our manuscript. We hope that we are able to address all of them with extensive manuscript changes as requested.

\section{Reviewer 1:}

1)The authors state that in the conventional way of outflow the aqueous passes into Schlemm's canal by paracytosis or giant vacuoles. This is a partial view that does not correspond to the truth. I invite the authors to read Saccà et al. The Outflow Pathway: A Tissue With Morphological and Functional Unity1.

Authors: Thank you for bringing this review article to our attention. We are pleased to use this publication and your other article as additional references. We have modified the 
Introduction to include more comprehensive details about conventional outflow better aligned with Saccà et al. We would like to change the less common phrase "paracytosis" with "paracellular passage through pores" to distinguish it from the active process of pathogen intrusion through epithelia e.g. by haemophilus.1 Overall, it appears our manuscript matches Saccà et al well who state that the main mechanisms of aqueous outflow are "a paracellular route [...] and a transcellular pathway". We have added to the Introduction the description of a transcellular pathway through intracellular pores 2 with inducible pore density that depends on outflow demand3.

In the reworded Introduction we now state: "The aqueous passes from the anterior chamber into Schlemm's canal (SC) by entering first the uveal TM (UTM), the corneoscleral TM (CTM) and finally the juxtacanalicular TM (JCT)4. The JCT contains proteoglycans and hyaluronans and presents the aqueous humor with an increasingly tighter fluid passageway towards the SC in a process referred to as funneling5. The aqueous eventually passes the inner wall of SC endothelium mainly by two different mechanisms, a paracellular route in between endothelial cells and a transcellular route 6 consisting of intracellular pores and giant vacuoles that are time and pressure dependent7-9. Failure of the TM and the inner wall of SC endothelial cells to maintain homeostasis and a normal cytoskeleton and can cause ocular hypertension 10 . For instance, pigment dispersion 11 and corticosteroids can increase and contract actin stress fibers and result in an elevation of the intraocular pressure (IOP)11,12. Conversely, relaxing the cytoskeleton with Rho kinase inhibitors can reverse these effects13,14. Phagocytosis of debris is another function of TM cells8. A chronic phagocytosis demand in the form of pigment15, erythrocyte-derived ghost cells16, inflammatory cells17, photoreceptor outer segments18, lens and pseudoexfoliation material19,20 can all lead to secondary glaucomas even though the amount of material itself is unlikely to cause a physical outflow obstruction. Although these glaucomas make for a sizable fraction of open angle glaucomas, it was difficult to study the cellular mechanism that leads to an IOP elevation."

2) Then the effects of the inhibitors of the Rho kinase inhibitor may have the ability to modify the metabolism of endothelial cells in the node in which the authors think it is open to question. These drugs have the ability to block TM motility by exposing more cells to aqueous humor. This is the reason why we initially witness a decline in IOP then this worsens because the exposed cells are blocked and are more exposed to apoptosis (to read Saccà et al. from DNA damage to functional changes of the trabecular meshwork in aging and glaucoma2).

Authors: We completely agree with the Reviewer. We would like to point out that consistent with Sacca et al - we wrote that "we hypothesized that ocular hypertension is the result of a reorganization of the actin cytoskeleton and occurs before phagocytosis declines." We did not intend to describe outflow through the TM as sink-like. We hope the expanded Introduction makes it more obvious that this is a paracellular and transcellular process.

In addition, we specifically stated before that "material itself is unlikely to cause a physical outflow obstruction" (Introduction), that granules "were not dense enough to physically obstruct any part of the conventional outflow system" (Results) and discuss that this had already been shown before: "Pigment treatment has previously been shown to cause ocular hypertension in part by reorganizing the TM actin cytoskeleton and not by physical obstruction of the outflow tract15,21." (Discussion). 
We now clarify in the Discussion that "Past investigations suggested that the outflow obstruction was, in fact, physical15,22 but newer studies indicated that ocular hypertension is in part caused indirectly by reorganization of the TM actin cytoskeleton23. Consistent with Zhou et al.23, we recently reported that long, thick, and continuous TM actin bundles emerge as early as 24 hours after pigment exposure 11 and replicate this observation in the present study."

3) Also the hypothesis formulated by the authors to explain the pigmentary glaucoma is partial in the Trabecolato the so-called pores have a very low meaning and above all the pigment does not obstruct anything. We do not work like sinks - I am amazed that today we can still believe that TM is a porous tissue, and above all, how it is possible to think that outflow is a passive phenomenon.

Authors: We did not state anything about an outflow obstruction or a location in our hypothesis. We wrote, "In the current study, we hypothesized that ocular hypertension is the result of a reorganization of the actin cytoskeleton and occurs before phagocytosis declines." As we detail in our Response to 3), we never wrote that the TM functions as a sink. On the contrary, we elaborate multiple times that there is no physical obstruction as detailed in our Response to 2 ). Please see our response above where we hope to clarify this point in the rewritten manuscript.

4) In pigmentary glaucoma there are 2 fundamental pathogenic moments. The first concerns the back sheet of the iris, where the pigment comes from (a defect that involves the loss of the pigment itself) the second point concerns autophagy which is not able to ensure adequate cell homeostasis. So these cells first enter suffering and then die and hence glaucoma is why the cells do not work, not because it obstructs something. There are cells, not tubes.

Authors: We completely agree as detailed in 1)-3) and have expanded our manuscript to make this more obvious.

5) The cytoskeleton in all this has little to do with it: pigment granules are only a metabolic burden that in the case of pigment dispersal syndrome is absorbed by a functioning autophagy, while in pigment glaucoma, autophagy does not work. Finally, I remember that the changes in the cytoskeleton occur in all types of glaucoma. I do not believe that this article can be indexed in this form and needs a remake of both the introduction and the discussion and the results should be reviewed in the light of a more modern interpretation of the physio-pathogenical events.

Authors: We are unsure why the Reviewer states that cytoskeletal changes have nothing to do with an IOP elevation after a phagocytosis challenge. This is rather well established: Zhou et al found that $4 \mathrm{~h}$ after phagocytosis, the cytoskeletal structure in trabecular meshwork cells was disrupted23. As we detail in the Introduction "pigment dispersion 11 and corticosteroids can increase and contract actin stress fibers and result in an elevation of the intraocular pressure (IOP)11,12. Conversely, relaxing the cytoskeleton with Rho kinase inhibitors can reverse these effects13,14."

The new finding described in this manuscript is that the IOP rises when the cytoskeleton changes occur as a result form pigment exposure but before phagocytosis starts to fail. This has not been observed before because an appropriate ex vivo anterior segment model of pigment dispersion did not exist. 
Our recent studies $11,24,25$ show that ex vivo perfused pig eyes experience reduced outflow in response to continuous exposure to pigment at a concentration far lower (10,000-fold) than that used in previous bolus experiments 26 and that severe cytoskeletal changes are associated with this. Conversely, we show that rho-kinase inhibitors normalize the cytoskeleton and the phagocytosis 24 . TM regulates aqueous outflow by changing its cytoskeleton, stiffness, cell adhesion, migration, contraction, and phagocytosis10,27, in which ROCK signaling plays a central role28,29. There is a close interaction between actin cytoskeleton reorganization, cell or extracellular matrix stiffness and aqueous outflow facility 30,31 . Only a small proportion of stress fiber formation was found in the normal TM culture while pigment exposure increased it by 2.06-fold 11 .

Lastly, we caution not to confuse TM cell phagocytosis of pigmented debris with autophagy. To address the Reviewer's concern we have added to the Discussion his own reference 32 and state that "An increased pigmentary debris may interfere with many intracellular functions, including important autophagy functions that can cause a gradual deterioration of TM cell function32,33."

\section{References used by Reviewer 1}

1. Saccà SC, Gandolfi S, Bagnis A, Manni G, Damonte G, Traverso CE, Izzotti A: The Outflow Pathway: A Tissue With Morphological and Functional Unity.J Cell Physiol. 2016; 231 (9): 1876-93 PubMed Abstract | Publisher Full Text

2. Saccà SC, Gandolfi S, Bagnis A, Manni G, Damonte G, Traverso CE, Izzotti A: From DNA damage to functional changes of the trabecular meshwork in aging and glaucoma.Ageing Res Rev. 2016; 29: 26-41 PubMed Abstract | Publisher Full Text

\section{References used by the Authors in this Reply}

1. van Schilfgaarde M, van Alphen L, Eijk P, Everts V, Dankert J. Paracytosis of Haemophilus influenzae through cell layers of NCI-H292 lung epithelial cells. Infect Immun. 1995

Dec;63(12):4729-4737. PMCID: PMC173678

2. Johnson M, Erickson K. Mechanisms and routes of aqueous humor drainage. Principles and Practice of Ophthalmology. Saunders Philadelphia; 2000;4:2577-2595.

3. Braakman ST, Pedrigi RM, Read AT, Smith JAE, Stamer WD, Ethier CR, Overby DR. Biomechanical strain as a trigger for pore formation in Schlemm's canal endothelial cells. Exp Eye Res. 2014 Oct;127:224-235. PMCID: PMC4175173

4. Saccà SC, Gandolfi S, Bagnis A, Manni G, Damonte G, Traverso CE, Izzotti A. The Outflow Pathway: A Tissue With Morphological and Functional Unity. J Cell Physiol. 2016 Sep;231(9):1876-1893. PMID: 26754581

5. Ethier CR, Coloma FM, Sit AJ, Johnson M. Two pore types in the inner-wall endothelium of Schlemm's canal. Invest Ophthalmol Vis Sci. 1998;39:2041-2048.

6. Alvarado JA, Betanzos A, Franse-Carman L, Chen J, González-Mariscal L. Endothelia of Schlemm's canal and trabecular meshwork: distinct molecular, functional, and anatomic features. Am J Physiol Cell Physiol. 2004 Mar;286(3):C621-34. PMID: 14613887

7. Johnstone MA, Grant WM. Pressure-dependent changes in structures of the aqueous outflow system of human and monkey eyes. Am J Ophthalmol. 1973 Mar;75(3):365-383. PMID: 4633234

8. Tamm ER. The trabecular meshwork outflow pathways: structural and functional aspects. Exp Eye Res. 2009 Apr;88(4):648-655. PMID: 19239914 
9. Braakman ST, Daniel Stamer W, Overby DR. A fluorescent permeability assay for Schlemm's canal endothelial cells in response to stretch. Invest Ophthalmol Vis Sci. The Association for Research in Vision and Ophthalmology; 2014 Apr 30;55(13):5983-5983.

10. Llobet A, Gasull X, Gual A. Understanding trabecular meshwork physiology: a key to the control of intraocular pressure? News Physiol Sci. 2003 Oct;18:205-209. PMID: 14500801

11. Dang Y, Waxman S, Wang C, Loewen RT, Sun M, Loewen N. A porcine ex vivo model of pigmentary glaucoma. Sci Rep [Internet]. 2018 Mar 26;8. Available from:

http://dx.doi.org/10.1038/s41598-018-23861-x

12. Pattabiraman PP, Rao PV. Mechanistic basis of Rho GTPase-induced extracellular matrix synthesis in trabecular meshwork cells. Am J Physiol Cell Physiol. 2010 Mar;298(3):C749-63. PMCID: PMC2838580

13. Tanihara H, Inoue T, Yamamoto T, Kuwayama Y, Abe H, Suganami H, Araie M, K-115 Clinical Study Group. Intra-ocular pressure-lowering effects of a Rho kinase inhibitor, ripasudil (K-115), over 24 hours in primary open-angle glaucoma and ocular hypertension: a randomized, open-label, crossover study. Acta Ophthalmol. 2015 Jun;93(4):e254-60. PMID: 25487877

14. Tanihara H, Inoue T, Yamamoto T, Kuwayama Y, Abe H, Araie M, K-115 Clinical Study Group. Phase 1 clinical trials of a selective Rho kinase inhibitor, K-115. JAMA Ophthalmol. 2013 Oct;131(10):1288-1295. PMID: 23787820

15. Epstein DL, Freddo TF, Anderson PJ, Patterson MM, Bassett-Chu S. Experimental obstruction to aqueous outflow by pigment particles in living monkeys. Invest Ophthalmol Vis Sci. 1986 Mar;27(3):387-395. PMID: 3949467

16. Campbell DG, Simmons RJ, Grant WM. Ghost cells as a cause of glaucoma. Am J Ophthalmol. 1976 Apr;81(4):441-450. PMID: 1266922

17. Moorthy RS, Mermoud A, Baerveldt G, Minckler DS, Lee PP, Rao NA. Glaucoma associated with uveitis. Surv Ophthalmol. 1997 Mar;41(5):361-394. PMID: 9163835

18. Callender D, Jay JL, Barrie T. Schwartz-Matsuo syndrome: atypical presentation as acute open angle glaucoma. Br J Ophthalmol. BMJ Publishing Group Ltd; 1997 Jul 1;81(7):608-608. 19. Lee RK. The molecular pathophysiology of pseudoexfoliation glaucoma. Curr Opin Ophthalmol. 2008 Mar;19(2):95-101. PMID: 18301281

20. Ritch R, Schlötzer-Schrehardt U, Konstas AGP. Why is glaucoma associated with exfoliation syndrome? Prog Retin Eye Res. 2003 May;22(3):253-275. PMID: 12852486 21. Gottanka J, Johnson DH, Grehn F, Lütjen-Drecoll E. Histologic findings in pigment dispersion syndrome and pigmentary glaucoma. J Glaucoma. 2006 Apr;15(2):142-151. PMID: 16633228

22. Alvarado JA, Murphy CG. Outflow obstruction in pigmentary and primary open angle glaucoma. Arch Ophthalmol. 1992 Dec;110(12):1769-1778. PMID: 1463421

23. Zhou L, Li Y, Beatrice Y J. Alteration of cytoskeletal structure, integrin distribution, and migratory activity by phagocytic challenge in cells from an ocular tissue-The trabecular meshwork. In Vitro CellDevBiol-Animal. Springer-Verlag; 1999 Mar 1;35(3):144-149.

24. Dang Y, Wang C, Shah P, Waxman S, Loewen RT, Loewen NA. Ocular Hypotension, Actin Stress Fiber Disruption and Phagocytosis Increase by RKI-1447, a Rho-Kinase Inhibitor [Internet]. 2018 [cited 2018 Feb 26]. Available from:

http://dx.doi.org/10.20944/preprints201802.0026.v1

25. Wang C, Dang Y, Loewen R, Waxman S, Shah P, Xia X, Loewen NA. Impact of Pigment Dispersion on Trabecular Meshwork Cells. ResearchGate preprint [Internet]. 2018 Jan 25 [cited 2018 Jan 25]; Available from: 
https://www.researchgate.net/publication/322627138_Impact_of_Pigment_Dispersion_on_Trabecular_Mesh 26. Epstein DL, Freddo TF, Anderson PJ, Patterson MM, Bassett-Chu S. Experimental obstruction to aqueous outflow by pigment particles in living monkeys. Invest Ophthalmol Vis Sci. 1986 Mar;27(3):387-395. PMID: 3949467

27. Abu-Hassan DW, Acott TS, Kelley MJ. The Trabecular Meshwork: A Basic Review of Form and Function. J Ocul Biol Dis Infor [Internet]. 2014 May;2(1). Available from:

https://www.ncbi.nlm.nih.gov/pubmed/25356439 PMCID: PMC4209746

28. Nakajima E, Nakajima T, Minagawa Y, Shearer TR, Azuma M. Contribution of ROCK in contraction of trabecular meshwork: proposed mechanism for regulating aqueous outflow in monkey and human eyes. J Pharm Sci. 2005 Apr;94(4):701-708. PMID: 15682386

29. Wang J, Liu X, Zhong Y. Rho/Rho-associated kinase pathway in glaucoma (Review). Int J Oncol. 2013 Nov;43(5):1357-1367. PMID: 24042317

30. Doornaert B, Leblond V, Planus E, Galiacy S, Laurent VM, Gras G, Isabey D, Lafuma C. Time course of actin cytoskeleton stiffness and matrix adhesion molecules in human bronchial epithelial cell cultures. Exp Cell Res. 2003 Jul 15;287(2):199-208. PMID: 12837276 31. Wang K, Read AT, Sulchek T, Ethier CR. Trabecular meshwork stiffness in glaucoma. Exp Eye Res. 2017 May 1;158:3-12.

32. Saccà SC, Gandolfi S, Bagnis A, Manni G, Damonte G, Traverso CE, Izzotti A. From DNA damage to functional changes of the trabecular meshwork in aging and glaucoma. Ageing Res Rev. 2016 Aug;29:26-41. PMID: 27242026

33. Liton PB, Lin Y, Gonzalez P, Epstein DL. Potential role of lysosomal dysfunction in the pathogenesis of primary open angle glaucoma. Autophagy. 2009 Jan;5(1):122-124. PMCID: PMC2745819

Competing Interests: No competing interest

The benefits of publishing with F1000Research:

- Your article is published within days, with no editorial bias

- You can publish traditional articles, null/negative results, case reports, data notes and more

- The peer review process is transparent and collaborative

- Your article is indexed in PubMed after passing peer review

- Dedicated customer support at every stage

For pre-submission enquiries, contact research@f1000.com

F1000Research 